\title{
Milk Production of Young Holstein Cows Fed only on Grass from Steep, Intensively Managed Tropical Grass Pastures over Three Successive Lactations, ${ }^{1,2}$
}

\author{
Rubén Caro-Costas and José Vicente-Chandler ${ }^{3}$ \\ INTRODUCTION
}

Dairy cows in Puerto Rico generally are fed on poorly managed pastures supplemented by 1 pound of 20- to 24-percent protein concentrate per liter (2.2 pounds) of milk produced. Concentrate dairy feeds worth over $\$ 30$ million are imported each year. Most dairies in Puerto Rico are located on expensive level or rolling lands, many of which are suited to mechanized crop production.

About 500,000 acres of land in the Humid Mountain Region are better suited to pastures because they are too steep for mechanized crop production and require the protection against erosion that grass pastures can best provide. Livestock production in this area can be "mechanized" by applying fertilizer and lime with broad-base tractors or aircraft, while harvesting the forage with grazing cattle.

Long-term grazing experiments in this area by Vicente-Chandler et al. $(3,4)$ have shown that steep, well fertilized pastures of tropical grasses can carry two head of growing cattle or more and produce over 1,000 pounds of gain in weight per acre yearly, or little less than similarly treated pastures on level lands. Caro and Vicente-Chandler (1) found that eight mature grade Holstein cows fed exclusively on an all-grass ration from steep intensively managed pastures of Pangola, Guinea and Napier grasses produced an average of 6,064 pounds of milk over an 8-month lactation period. VicenteChandler et al. (3) report that a second group of 10 mature grade Holsteins on all grass rations on these same pastures produced an average of 6,369 pounds of milk over a 270-day lactation.

1 Manuscript submitted to the Editorial Board July 18, 1973.

3 This paper covers research conducted cooperatively by the Agricultural Research Service, U.S. Department of Agriculture, and the Agricultural Experiment Station, Mayagũez Campus, University of Puerto Rico, Río Piedras, P.R.

Special appreciation is due to Mr. Ramón González-Hernandez, who provided the pastures and fertilizer for this experiment and has set up the first commercial dairy based on the research reported in this paper.

- Agronomist, and Research Leader and Soil Scientist, Agricultural Research Service, U.S. Department of Agriculture and cooperative between ARS, USDA and the Agricultural Experiment Station, Mayagüez Campus, University of Puerto Rico, Río Piedras, P.R. 
The present study determined the effect of all-grass rations from steep intensively managed tropical grass pastures on milk production by nine young Holstein cows of good genetic capability over three successive lactation periods.

\section{MATERIALS AND METHODS}

The experiment was conducted near Orocovis at an elevation of 2,000 feet. Average monthly temperatures here range from $70^{\circ}$ to $80^{\circ} \mathrm{F}$., with highest daily temperatures rarely exceeding $90^{\circ} \mathrm{F}$. and the annual rainfall of about 65 inches is fairly well distributed throughout the year. The soil is deep, acid, red, well-drained Humatas (an Ultisol) clay on 50-percent slopes.

Ten 1-acre pastures of Pangola, Napier, Star and Guinea grasses were used in this experiment. All pastures were provided with drinking water, salt, and steamed bonemeal and received 500 pounds of 15-5-10 fertilizer per acre every 3 months. Soil pH was maintained at about 5.5 by periodic liming. The 10 pastures were grazed in rotation for 2 days with 18 days of rest between grazings and abundant forage of good quality was available to the cows at all time.

Forage samples, obtained by plucking in a manner simulating grazing, were taken monthly from all pastures and analyzed to determine their crude protein content.

Nine Holstein heifers of good genetic milk production capability were raised on an all-grass ration, then grazed on the 10 acres of pastures for three successive lactations without supplementary feeding of concentrates. The cows remained on the pastures at all times and grazed at will day and night except when being milked. They were hand-milked twice daily and the amount produced by each cow recorded. Lactations were terminated 2 months before calving or when daily production dropped below 10 pounds. The cows were bred 2 months after calving.

\section{RESULTS AND DISCUSSION}

The young cows in their first lactation produced an average of 4,497 pounds of milk over a 263 day lactation or an average of 7.8 liters daily (table 1). This rather low production even for first calf heifers was due probably to their small size at calving suggesting that cows to be fed on an all-grass ration should be bred to calve at over 1,000 pounds in weight.

The following tabulation shows the cows increased in weight from an average of only 929 pounds at the start of the first lactation to 1,148 at the end of the third lactation indicating that the all-grass ration provided sufficient nutrients for high-milk yields as well as for growth and main- 
tenance:

\author{
Weighing time \\ Start of first lactation \\ End of first lactation \\ Start of second lactation \\ End of second lactation \\ Start of third lactation \\ End of third lactation
}

Average weight of cows

(pounds)

$$
\begin{array}{r}
929 \\
1,019 \\
1,038 \\
1,076 \\
1,103 \\
1,148
\end{array}
$$

\begin{tabular}{|c|c|c|c|c|c|c|}
\hline \multirow[b]{2}{*}{ Cows } & \multicolumn{3}{|c|}{ Milk production (pounds) } & \multicolumn{3}{|c|}{ Length of lactation (days) } \\
\hline & $\begin{array}{c}\text { First } \\
\text { lactation }\end{array}$ & $\begin{array}{c}\text { Second } \\
\text { lactation }\end{array}$ & $\begin{array}{c}\text { Thind } \\
\text { lactation }\end{array}$ & $\underset{\text { lactation }}{\text { First }}$ & $\begin{array}{c}\text { Second } \\
\text { lactation }\end{array}$ & $\begin{array}{c}\text { Third } \\
\text { lactation }\end{array}$ \\
\hline \multicolumn{7}{|l|}{ number } \\
\hline 64 & 4,799 & 6,630 & 9,326 & 262 & 279 & 271 \\
\hline 155 & 4,769 & 8,780 & 9,084 & 256 & 290 & 277 \\
\hline 648 & 3,587 & 9,103 & 8,810 & 262 & 288 & 272 \\
\hline 166 & 4,234 & 7,302 & 8,745 & 271 & 280 & 302 \\
\hline 687 & 4,217 & 6,966 & 7,771 & 263 & 297 & 260 \\
\hline 188 & 4,591 & 8,966 & 7,167 & 298 & 307 & 288 \\
\hline 153 & 4,605 & 7,853 & 7,953 & 229 & 298 & 275 \\
\hline 194 & 3.998 & (aborted) & 9.434 & 233 & (aborted) & 290 \\
\hline 163 & 5,675 & 9,457 & 8,868 & 297 & 280 & 283 \\
\hline Average & 4,497 & 8,132 & 8,573 & 263 & 290 & 280 \\
\hline $\begin{array}{l}\text { Average daily } \\
\text { production } \\
\text { (liters) }\end{array}$ & 7.8 & 12.7 & 13.9 & & & \\
\hline
\end{tabular}

Table 1.-Mille produced over the first three lactations by nine Holstein cows fed exclusively on an all-grass ration from steep intensively managed tropical grass pastures

During their second lactation these young cows on an all-grass ration sharply increased their milk production to an average of 8,132 pounds over an average 290 day lactation (table 1). This increase is attributed to increased age and size of the cows.

During the third consecutive lactation on an all-grass ration these nine now mature cows (fig. 1) produced an average of 8,573 pounds of milk over a 280-day lactation or an average of 13.9 liters daily (table 1 ).

To produce this amount of milk and maintain bodyweights of about 1,150 pounds, the cows would have to ingest a total of 5,600 pounds of 
TDN or 9,030 pounds of dry forage of 60 -pereent digestibility over a 300 day lactation period. This is equivalent to an average of 30 pounds of dry forage daily or 130 pounds of green forage containing 23 percent of dry matter. Higher intakes would be required during the first months of lactation. Therefore, cows producing milk on all-grass rations must have highquality forage available at all times.

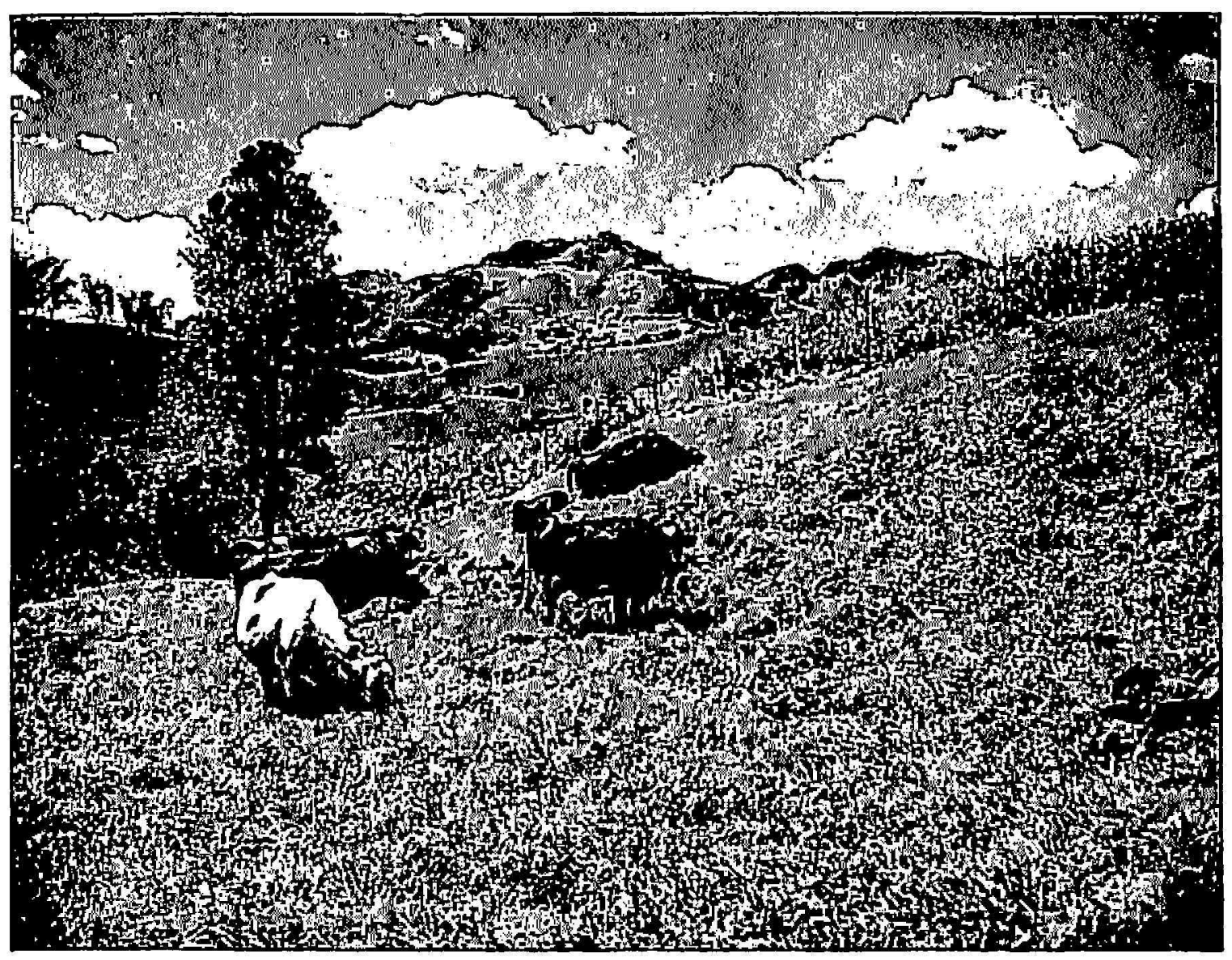

FIG. 1.-Holstein cows fed exclusively on these steep intensively managed tropical grass pastures in the humid mountain region produced an average of 8,573 pounds of milk during their third consecutive lactation on an all-grass ration. The pastures received 1 ton of 15-5-10 per acre yearly and carried one cow per acre at all times.

Average lactation curves for the three consecutive lactations (fig. 2) appear normal for the production levels attained.

Calving intervals averaged 12.4 and 12.3 months between the first and second and the second and third lactations, respectively.

Health problems wore minimal and confined to occasional mastitis and an abortion which resulted in the loss of one lactation.

The following tabulation shows that the grass ingested by the grazing cattle contained from 16.5 to 20.2 pereent of protein with highest contents 


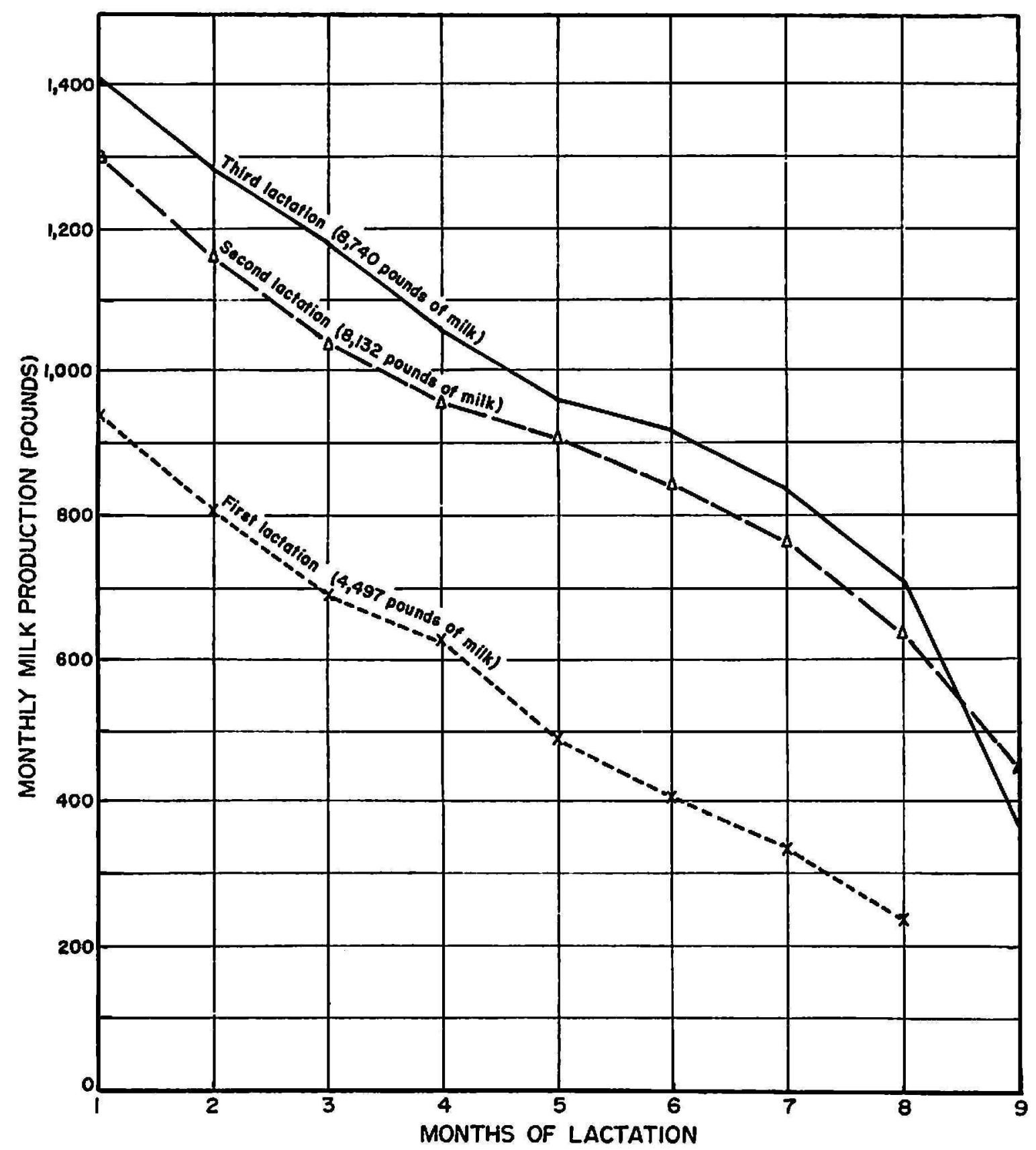

Fig. 2.- $A$ verage lactution curves for the first 3 lactations of 9 Holstein cows fed exclusively on an all-grass ration from steep, intensively managed tropical grass pastures.

occurring during the winter months of slow grow th:

\section{Monlh}

Jan.-Feb.

Mar.-Apr.

May-June

July-Aug.

Sept.-Oct.

Nov.-1)ee.

\section{Protein conlenl} (percenl)

20.2

18.1

16.5

17.6

18.7

20.1 
An economic model based on the results obtained in these experiments was developed by Serra, Vicente-Chandler and Lloréns (2) for an assumed $16 \overline{-}$-acre farm with 153 acres in intensively managed pastures in the humid hill or mountain region. The model assumed deep soils with slopes less than 50 percent, and rainfall of more than 65 inches fairly well distributed throughout the year. During exceptionally dry years, occurring about once per decade, supplementary feeding of concentrate may become necessary, increasing production costs considerably during that year.

The herd of 150 milk cows should have a calving interval of $131 / 2$ months with 135 lactations yearly, averaging 3,000 liters per lactation. The cows are provided with abundant salt, water and ground bonemeal, but receive no concentrate feed. Thirty cows, five of which are lost due to disease and accident, are replaced annually. The cows are bred to three bulls costing about $\$ 1,000$ each and sold at approximately their purchase price after 3 years of service, to avoid inbreeding. The owner substitutes for milkers and helps in farm operations as required.

The intensively managed grass pastures, preferably of Star, carry one cow per acre and receive 1 ton of ground limestone and 1 ton of 15-5-10 fertilizer per acre yearly, the latter applied in four equal applications. Cows are divided into two groups which graze two sets of five pastures each in rotation with 5 to 7 days of grazing followed by 20 to 28 days of rest.

Table 2 shows that such a dairy with cows fed exclusively on intensively managed pastures would yicld a yearly net income of $\$ 21,342$, a cash income of $\$ 44,228$ with 15.5-percent return on capital investment. Net cost of producing a liter of milk would be about 15 cents if income from sale of calves and culled cows is deducted from total costs for the dairy.

This model readjusted to reflect current prices of milk at 27 cents per quart, fertilizer at $\$ 80$ per ton, replacements at $\$ 500$ per head, and interest at 8-percent, net income would show an increase to $\$ 39,945$ yearly and cash income to $\$ 63,753$.

The high productivity of cows receiving no concentrate feed and grazing steep intensively managed pastures in the humid mountain region has important economic implications for Pureto Rico. Such a system would make more complete use of the Island's soil and climatic resoures in the hill and mountain region where the land has few alternative uses. Livestock operations on these lands can be largely mechanized by applying fertilizers with broad-base tractors or aircraft, while the cows harvest the forage by grazing. Furthermore, imports of concentrates from the U.S. mainland, now exceeding $\$ 30$ million yearly, could be sharply decreased.

Based on the results of these experiments Mr. Ramón González has established a 150-cow dairy at Orocovis to produce milk with Holsteins fed exclusively on steep intensively managed grass pastures. The nine 
cows used in the experiments described in this paper and now in their fourth lactation have been incorporated into this commercial herd.

These experiments show clearly that millions of acres of rolling to steep lands in the Humid Tropies which have few alternative uses could be devoted to milk production based exclusively on intensively managed pastures of tropical grasses.

TABLE 2.-Estimated anmual costs and profits from a 150-cove dairy in the humid hill or mountain region wilh cous jed exclusively on inlensively managed grass pastures

\begin{tabular}{|c|c|c|c|}
\hline \multicolumn{2}{|l|}{ Costs 1} & \multicolumn{2}{|l|}{ Income } \\
\hline & Dollars & & Dollars \\
\hline Owner's time & 6,000 & Sule of milk at s0.20/liter & 81,000 \\
\hline Laborers (4 at $\$ 3,000)$ & 12,000 & (135 lactations $\times 3,000$ & \\
\hline Fertilizer (153 tons/\$65) & 9,945 & liters) & \\
\hline Limestone (153 lons/\$!)) & 1,377 & Sale of culled cows for beef & 5,000 \\
\hline Other materials & 1,900 & $(25 / \$ 200)$ & \\
\hline $\begin{array}{l}\text { Taxes (property, Social se- } \\
\text { curity, health insurance) }\end{array}$ & 2,700 & $\begin{array}{l}\text { Sale of ealves for beef }(110 / \\
\$ 25)\end{array}$ & 2,750 \\
\hline lilectricity, water & 1,000 & Total income & 88,750 \\
\hline Miscellaneous expensrs & 2,800 & Net income & 21,342 \\
\hline $\begin{array}{l}\text { Purchase of replacements ( } 30 \\
\text { at } \$ 100 \text { ) }\end{array}$ & 12,000 & $\begin{array}{l}\text { Cash income } \\
\text { lieturn on capital }\end{array}$ & $\begin{array}{l}4,228 \\
15.5 \%\end{array}$ \\
\hline $\begin{array}{l}\text { Interest on operating capital } \\
(\$ 10,000 \text { at } 8(i)\end{array}$ & 800 & 1 Capital investment: & Dollars \\
\hline $\begin{array}{l}\text { Deprecintion of huildings } \\
\text { (\$20,000 over } 20 \text { yenrs) }\end{array}$ & 1,000 & $\begin{array}{l}\text { Land (165 acres/S600) } \\
\text { Cows }(150 / \mathrm{S} 400)\end{array}$ & $\begin{array}{l}99,000 \\
60,000\end{array}$ \\
\hline $\begin{array}{l}\text { Depreciation of equipment } \\
\text { (\$10,000 over } 10 \text { years) }\end{array}$ & 1,000 & $\begin{array}{l}\text { Bulls ( } 3 / \$ 1,000) \\
\text { Buildings }\end{array}$ & $\begin{array}{r}3,000 \\
20,000\end{array}$ \\
\hline $\begin{array}{l}\text { 1)preciation of pastures } \\
\text { (\$30,600 over } 20 \text { years) }\end{array}$ & 1,530 & $\begin{array}{l}\text { Equipment } \\
\text { l'astures, fences, ete. }\end{array}$ & $\begin{array}{l}10,000 \\
30,600\end{array}$ \\
\hline $\begin{array}{l}\text { Interest on capital invest- } \\
\text { ment' (S222,600 at 6\%; ) } \\
\text { Total cost }\end{array}$ & $\begin{array}{r}13,356 \\
S 67,408\end{array}$ & Total & $\$ 222,600$ \\
\hline
\end{tabular}

\section{SUMMARY}

Milk produed during their first three lactations by nine Holsteins fed exclusively on all-grass rations from steep tropical grass pastures in the humid mountain region of Puerto Rico was determined.

The pastures, which received 1 ton of 15-5-10 por acre yearly, carried one cow per acre with no supplementary fecd. Grass consumed by the grazing cows contained from 16.5 to 20.2 pereent of protein depending on the season of the year.

The cows produced an average of $4,497,8,132$, and 8,573 pounds of milk during their first, second and third lactations, respectively. The lactations 
averaged 263,290 , and 280 days in length, respectively, with an average calving interval of 12.3 months. The cows weighed an average of 929 pounds at first calving, increasing to 1,148 pounds at the third calving.

An economic model based on these results shows that feeding cows on all-grass rations from intensively managed steep pastures can be highly profitable in the mountain region of Puerto Rico where the land has few alternative uses.

\section{RESUMEN}

Se determinó la producción de leche en tres lactancias sucesivas de nueve vacas Holstein alimentadas exclusivamente con yerba, en pastos con declive en la región montañosa húmeda de Puerto Rico.

Los pastos, que se abonaron con 1 tonclada de la fórmula 15-5-10 por acre al año, mantuvicron una vaca por acre sin alimento suplementario alguno. El forraje ingerido por las vacas al pastar contenía de 16.5 a 20.2 por ciento de proteína, dependiendo de la época del año.

Las vacas produjeron un promedio de 4,497, 8,132 y 8,573 libras de leche durante su primera, segunda y tercera lactancias, respectivamente. Las lactancias duraron un promedio de 263,290 y 280 dias, respectivamente, con un intervalo promedio de 12.3 meses entre partos. Las vacas pesaron un promedio de 929 libras al parir por primera vez, aumentando a 1,148 libras en el tereer parto.

Un modelo rconómico basado en estos resultados demuestra que la alimentación de vacas exclusivamente con pastos cultivados intensivamente (n la región montañosa de Puerto Rico puede ser muy gananciosa.

\section{LITERATURE CITED}

1. Caro-Costas, R., and Viecnte-Chandler, J., Milk Production with all-grass rations from steep intensively managed tropical pastures, J. Agr. Univ. P.R. $53(4)$ : 251-8, 1969.

2. Serra, G., Vicente-Chandler, J., and Lloréns, A., Aspectos Económicos de la Ganadería en Pastos Intensivamente Cultivados en la Altura Húmeda de Puerto Rico, Publ. 83, Agr. Exp. Sta. Univ. P.R. (in press).

3. Vicente-Chandler, J., Abruña, F., Caro, R., Figarella, J., Silva, S., and Pearson, R. W., Intensive Grassland Management in the Humid Tropies of Puerto Rico, Agr. Exp. Sta. Univ. P.R. Bull. 233 (in press).

4. - Caro-Costas, R., Pearson, R. W., Abruña, F., Figarella, J., and Silva, S., The Intensive Management of Tropical Forages in Puerto Rico, Agr. Exp. Sta. Univ. P.R. Bull. 187, 152 pp., 1964. 